3. B. Wortmann, W. Wortmann, and J. C. Touchstone, J. Chromatogr., 70, 199 (1972).

4. H. H. Lon, J. K. Ho, W. R. Lipscomb, T. M. Cho, and C. Selewski, J. Chromatogr., 68, 289 (1972).

5. H. P. Raanen, J. Chromatogr., 53, 600 (1967).

6. J. T. Huang, K. T. Wang, J. Chromatogr., 31, 587 (1967).

\title{
Sedum ALKALOIDS
}

\author{
E. A. Krasnov, L. V. Petrova, \\ and E. F. Bekker
}

UDC 547/945

The alkaloids of Sedum acre (goldmoss stonecrop) have been considered in various publications [1-5]. We have investigated the alkaloid compositions of the epigeal parts of four Siberian species of Sedum: $S_{\text {a }}$ aizoon L. (aizoon stonecrop), S. purpureum (L.) Shult. (purple stonecrop), $S_{\circ}$ hydridum L. (evergreen stonecrop), and S. ewersii Ledeb. (Ewers stonecrop), collected in the Tomsk oblast (village of Urtam) and in the Gorno-Altai A Autonomous Region (villages of Maima and Kebezen') in the flowering phase.

The combined bases were isolated by Franck's method [4]. TLC on plates coated with $\mathrm{Al}_{2} \mathrm{O}_{3}$ in the benzene-methanol (85:15) (system 1) and ethyl acetate-chloroform-methanol (2.5:2.0:0.5) (system 2) systems showed that the first three species have the same qualitative composition (each containing three bases),

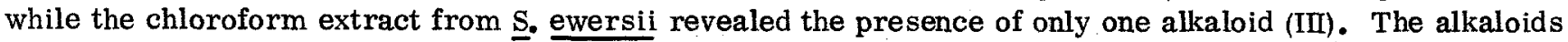
were separated on comumn of alunina (activity grade II, neutral) being eluted successively with benzene and mixtures of benzene with $5-25 \%$ of methanol.

Base (I) was isolated in the form of a colorless oily residue with $R_{f} 0.89$ (system 1) and 0.86 (system 2) and gave a picrate with $\mathrm{mp} 156-158^{\circ} \mathrm{C}$. IR spectrum, $\mathrm{cm}^{-1}: 2950\left(\mathrm{CH}_{3}\right), 1690(\mathrm{C}=0)$. On the basis of these results, the substance was identified as $( \pm)$-methly isopelletierine [6].

Base (II), mp $119-121^{\circ} \mathrm{C}, \mathrm{R}_{\mathrm{f}} 0.28$ (system 1) and 0.75 (sy stem 2) decolorized a solution of potassium permanganate and bromine water. Its IR spectrum showed absorption bands at $\left(\mathrm{cm}^{-1}\right) 3385(\mathrm{OH}), 2935\left(\mathrm{CH}_{3}\right), 1630$ ( $\pi$-bond), 1590 (aromatic ring), and 760, 745 (monosubstituted benzene nucleus). It formed a hydrochloride with mp $169-170^{\circ} \mathrm{C},[\alpha]_{\mathrm{D}}^{20}-140^{\circ} \mathrm{C}\left(\mathrm{c} 0.04 ; \mathrm{CH}_{3} \mathrm{OH}\right)$. The base was identified as (-)-sedinine [7].

Base (III), $\mathrm{mp} 89-90^{\circ} \mathrm{C}, \mathrm{R}_{\mathrm{f}} 0.22$ (system 1) and 0.61 (system 2). IR spectrum, $\mathrm{cm}^{-1}$ : $3280(\mathrm{OH}), 2955\left(\mathrm{CH}_{3}\right.$ ), 1570,1485 (benzene ring). The substance formed a hydrochloride with $\mathrm{mp} 186-188^{\circ} \mathrm{C}$. The results obtained permitted the conclusion that base (III) was $( \pm)$-sedamine $[4,8]$. A direct comparison with $( \pm)$-sedamine confirmed their identity.

\section{LITERATURE CITED}

1. D. G. Kolesnikov and A. G. Shvartsman, Zh. Obshch. Khim., 9, 2156 (1939).

2. A. Nordal, A Pharmacognostical Study of Sedum acre L., Oslo (1946).

3. L. Marion, R. Lavigne, and L. Lemay, Canad. J. Chem. 29, 347 (1951).

4. B. Franck, Chem. Ber., 91, 2803 (1958).

5. B. Franck and W. Hartmann, Abhandl. Deut. Akad. Wiss., 4, 111 (1963).

6. L. Marion and M. Chaput, Canad. J. Research, 27B, 213 (1949).

7. B. Franck, Chem. Ber., 92, 1001 (1959).

8. L. Marion, Canad. J. Research, 23B, 165 (1945).

Tomsk Medical Institute. Translated from Khimiya Prirodnykh Soedinenii, No. 4, p. 585, July-August, 1977. Original article submitted March 3, 1977.

This material is protected by copyright registered in the name of Plenum Publishing Corporation, 227 West 17th Street, New York, N.Y. 10011. No part of this publication may be reproduced, stored in a retrieval system, or transmitted, in any form or by any means, electronic, mechanical, photocopying, microfilming, recording or otherwise, without written permission of the publisher. A copy of this article is available from the publisher for $\$ 7.50$. 